\author{
Board of Governors of the Federal Reserve System \\ International Finance Discussion Papers \\ Number 502 \\ February 1995
}

STRATEGIC RETURNS TO INTERNATIONAL DIVERSIFICATION:

AN APPLICATION TO THE EQUITY MARKETS OF EUROPE, JAPAN, AND NORTH AMERICA

John Ammer

Jianping Mei

NOTE: International Finance Discussion Papers are preliminary materials circulated to stimulate discussion and critical comment. References in publications to International Finance Discussion Papers (other than an acknowledgment that the writer has had access to unpublished material) should be cleared with the author or authors. 


\begin{abstract}
We undertake a decomposition of the risk factor loadings of fifteen national stock market returns from 1972 to 1990 , using a variant of the Campbell-Shiller (1988) linearization. We find considerable variation among countries in the relative importance of a cash flow component and a discount rate component in determining the beta with the world equity index return and with other risk factors. Also, the international heterogeneity we find in factor loadings suggests that a global portfolio allows substantial hedging opportunities, presumably deriving from differences in underlying economic structure.
\end{abstract}




\title{
Strategic Returns to International Diversification: An Application to the Equity Markets of Europe, Japan, and North America
}

\author{
John Ammer and Jianping $\mathrm{Mei}^{1}$
}

\section{Introduction}

Lately, there has been increasing interest in measuring the risks associated with international equity investment. In this paper, we analyze the sensitivity of fifteen national stock market returns to several global risk factors, including the world stock portfolio return. We first restate an expression derived by Campbell (1991) relating the unexpected excess return on any asset to news about its future cash flows and future discount rates. We show how to construct empirical proxies for these sources of news, and we use these proxies to decompose the factor loadings of returns into cash flow betas and expected return betas.

We combine two common modes of analysis in finance: cross-sectional analysis of multiple risk factor models and traditional fundamental analysis that uses the present value relation. The former analysis breaks risk down into sensitivities to various factors, while the latter distinguishes between cash flow risk and discount rate risk. Here we use both contemporaneous cross-sectional information and time-series information to describe the dynamic behavior of asset returns.

In our empirical application, we find that, on average, both the cash flow component and the discount rate component contribute to the world market beta and other risk factor

${ }^{1}$ The first author is a staff economist in the International Finance Division of the Federal Reserve Board and the second author is Assistant Professor of Finance in the Stern School of Business at New York University. Opinions expressed herein do not necessarily concur with those of the Federal Reserve Board or any other employees of the Federal Reserve System. The authors are grateful to Stephen Brown for providing some of the international stock market data but are solely responsible for any errors. 
loadings, although there is substantial cross-country variation in their relative importance.

Second, for most countries, variation in expected returns on the national stock market has the effect of increasing its sensitivity to the world market. Third, cash flow betas and expected return betas often have offsetting effects on the overall betas of assets with economic state variables. Fourth, some assets have positive betas towards some of the state variables while others have negative betas towards these variables. This is interesting because it tells us how particular global economic risks can be reduced through a diversified international portfolio.

The paper is divided into five sections. In the next section, we present an approximate present value model in which we decompose excess returns into three different components: innovations (or news) about dividend growth, interest rates, and future expected returns. We then use the three components to compute the cash flow beta, the interest rate beta, and the future return beta in the following section. This framework is derived by Campbell and Mei (1993). In the fourth section, we present our empirical results. The final section summarizes our conclusions.

\section{Decomposing Stock Returns}

We first use an excess return version of the Campbell (1991) approximate present value relation to characterize the innovation in the domestic stock return as news about future dividends, interest rates, and equity risk premiums: ${ }^{2}$

\footnotetext{
${ }^{2}$ An approximate intertemporal identity is derived by taking a first-order Taylor expansion of an accounting identity for the log one-period return, computing the forward solution of the resulting difference equation in the log of the dividend-price-ratio, and applying expectations operators. The only assumption we make here is to impose a consistency condition on expectations that is somewhat weaker than rational expectations. For
} 


$$
\tilde{e}_{t+1}=\left(E_{t+1}-E_{t}\right)\left\{\sum_{j=0}^{\infty} \rho^{j} \Delta d_{t+1+j}-\sum_{j=0}^{\infty} \rho^{j} r_{t+1+j}-\sum_{j=1}^{\infty} \rho^{j} e_{t+1+j}\right\}
$$

where $r$ is the one-period treasury bill return, $e$ is the excess return on equity (over the treasury bill), and $d$ is the dividend paid. All variables are measured in real terms and in logs, a tilde $(\sim)$ superscript represents an innovation in a variable, and a delta $(\Delta)$ designates a first difference. Thus ẽ is the equity excess return innovation, and $\Delta \mathrm{d}$ is the log change in real dividends. We use $E_{t}$ to denote expectations formed at the end of period $t$, while $\left(E_{t+1}-E_{t}\right)$ is the revision in expectations given new information arrived during period $t+1$. The parameter $\rho$ is a constant of linearization that is slightly less than one. ${ }^{3}$

For convenience, we define simpler notation to refer to the three news components above:

$$
\tilde{e}=\tilde{e}_{d}-\tilde{e}_{r}-\tilde{e}_{e}
$$

Each term in (2) corresponds to one of the summations in (1). Equation (2) says that, ceteris paribus, news that dividends will grow more rapidly in the future would have a positive impact on today's stock return. On the other hand, an upward revision to expected future excess returns on stocks, accompanied with no information about future dividends or interest rates, means that the current stock price will have to drop, so that higher future returns can be

details, see Campbell (1991) or Campbell and Ammer (1993).

${ }^{3}$ It is approximately equal to the inverse of the mean of the gross income return on stocks, or about .997 for our world stock market measure. 
generated from the same cash flow. In other words, an unexpected increase in the equity risk premium generates an immediate capital loss. Similarly, positive revisions to future interest rate expectations reduce the current return on equity.

In order to apply equation (2), we need some means by which to compute expectations of the variables in equation (1). Rather than rely on a specific theoretical model, we assume expectations are generated by a vector autoregression (VAR). Previous studies have found that dividend yields and interest rates have significant forecasting power for stock returns. ${ }^{4}$ Accordingly, our VAR specification includes the dividend-price ratio for the world stock market index and the (ex post) real treasury bill rate, as well as world average measures of inflation and industrial production growth.

Forecasts for $\mathrm{r}$ and e from the VAR are used to calculate both the excess return innovations and the components of these innovations that are associated with interest rates and excess returns, as defined in equations (1) and (2). The dividend growth components can then be inferred by rearranging (2) as

$$
\tilde{e}_{d}=\tilde{e}+\tilde{e}_{r}+\tilde{e}_{e}
$$

\section{Decomposing Beta}

In this paper we define beta using unconditional variances and covariances of innovations in returns and factors. That is, we study the unconditional covariance of the

${ }^{4}$ See, for example, Ferson and Harvey (1991), Fama and French (1988a), (1988b), (1989), and Keim and Stambaugh (1986). 
return innovation with a factor innovation, divided by the unconditional variance of the factor innovation. This is neither a full conditional beta (which would use conditional variances and covariances), nor a straightforward unconditional beta (which would use returns themselves rather than innovations in returns). Beta as defined here has the advantage that it can be broken into components in a relatively simple way. If all elements of the conditional variance-covariance matrix of innovations are constant or changing in proportion to one another, then our beta equals the full conditional beta. Under these conditions, asset pricing theory can be used in a deeper analysis of beta, but for the present, we simply take our beta as a useful summary measure of an asset's sensitivity to a factor.

The most familiar type of beta is a market beta. Our definition of the market beta is

$$
\beta_{i, m} \equiv \frac{\operatorname{Cov}\left(\tilde{e}_{i}, \tilde{e}_{m}\right)}{\operatorname{Var}\left(\tilde{e}_{m}\right)}
$$

Here $\tilde{\mathrm{e}}_{\mathrm{i}}$ is the unexpected excess return on asset $\mathrm{i}$ and $\tilde{\mathrm{e}}_{\mathrm{m}}$ is the unexpected excess return on the market. (For notational simplicity we suppress time subscripts on these and similar variables wherever possible.) Equation (2) allows us to decompose $\beta_{\mathrm{i}, \mathrm{m}}$ as

$$
\begin{aligned}
\beta_{i, m} & =\frac{\operatorname{Cov}\left(\tilde{e}_{d i}, \tilde{e}_{m}\right)}{\operatorname{Var}\left(\tilde{e}_{m}\right)}-\frac{\operatorname{Cov}\left(\tilde{e}_{r}, \tilde{e}_{m}\right)}{\operatorname{Var}\left(\tilde{e}_{m}\right)}-\frac{\operatorname{Cov}\left(\tilde{e}_{e i}, \tilde{e}_{m}\right)}{\operatorname{Var}\left(\tilde{e}_{m}\right)} \\
& =\beta_{d i, m}-\beta_{r, m}-\beta_{e i, m}
\end{aligned}
$$


where $\beta_{\mathrm{di}, \mathrm{m}}$ is the market beta of news about asset i's future cash flows, $\beta_{\mathrm{r}, \mathrm{m}}$ is the market beta of news about future real interest rates, and $\beta_{\mathrm{ei}, \mathrm{m}}$ is the market beta of news about asset i's future excess returns.

More generally, one may want to work with $\mathrm{K}$ common factors in asset returns. Our definition of beta with the $\mathrm{k}_{\mathrm{th}}$ factor $\tilde{\mathrm{f}}_{\mathrm{k}}$ is

$$
\beta_{i, k} \equiv \frac{\operatorname{Cov}\left(\tilde{e}_{i}, \tilde{f}_{k}\right)}{\operatorname{Var}\left(\tilde{f}_{k}\right)}
$$

Equation (2) allows us to decompose this beta as follows:

$$
\begin{aligned}
\beta_{i, k} & =\frac{\operatorname{Cov}\left(\tilde{e}_{d i}, \tilde{f}_{k}\right)}{\operatorname{Var}\left(\tilde{f}_{k}\right)}-\frac{\operatorname{Cov}\left(\tilde{e}_{r}, \tilde{f}_{k}\right)}{\operatorname{Var}\left(\tilde{f}_{k}\right)}-\frac{\operatorname{Cov}\left(\tilde{e}_{e i}, \tilde{f}_{k}\right)}{\operatorname{Var}\left(\tilde{f}_{k}\right)} \\
& =\beta_{d i, k}-\beta_{r, k}-\beta_{e i, k}
\end{aligned}
$$

Equations (5) and (7) give the basic decomposition we use in our empirical work.

In order to implement our beta decomposition, we need to construct empirical proxies for news about future cash flows, excess returns, and real interest rates. To do this, we assume that we observe $\mathrm{N}$ excess returns over a 1-month Treasury bill return. The first excess return is on the value-weighted market portfolio of stocks. We postulate that expectations of these excess returns are linear in a vector of state variables $x_{t}$ with $K$ elements $\mathrm{x}_{\mathrm{k}}, \mathrm{k}=1, \ldots, \mathrm{K}$. The first of these elements is the excess return on the market and the second 
is the real return on a 1-month Treasury bill, while the other elements are variables known to the market by the end of period t. Thus the excess return on any asset can be written as

$$
e_{i, t+1}=a_{i}^{\prime} x_{t}+\tilde{e}_{i, t+1}
$$

for some K-element column vector $\mathrm{a}_{\mathrm{i}}$. The expected excess return on the market is given by $a_{1}^{\prime} x_{t}$, and the unexpected excess return on the market is $\tilde{e}_{1, t+1}$.

Next we assume that the state vector follows a first-order VAR:

$$
x_{t+1}=\Pi x_{t}+\tilde{x}_{t+1}
$$

where we again use the notational convention that $\tilde{x}_{t+1}$ is the innovation in $x_{t+1}$. The assumption that the VAR is first-order is not restrictive since a higher-order VAR can always be rewritten in first-order form as discussed by Campbell and Shiller (1988) among others. The matrix $\Pi$ is known as the companion matrix of the VAR. The assumptions we have made imply that $a_{1}^{\prime}$ is the first row of $\Pi$. Given the VAR model, revisions in long-horizon expectations of $x_{t+1}$ are:

$$
\left(E_{t+1}-E_{t}\right) x_{t+j+1}=\Pi^{j} \tilde{x}_{t+1}
$$

Finally, we define $\mathfrak{r}_{2}$ to be an L-element column vector the second element of which is one with all other elements equal to zero. This vector picks the real interest rate out of the state vector. Then equation (10) and the definitions of $\tilde{e}_{\mathrm{di}}, \tilde{\mathrm{e}}_{\mathrm{r}}$, and $\tilde{\mathrm{e}}_{\mathrm{ei}}$ in (2) imply that the components of asset returns can be written as 


$$
\begin{gathered}
\tilde{e}_{e i}=\rho a_{i}^{\prime}(I-\rho \Pi)^{-1} \tilde{x}_{t+1}, \\
\tilde{e}_{d i}=\tilde{e}_{i, t+1}+\left(\mathfrak{l}_{2}^{\prime}+\rho a_{i}\right)(I-\rho \Pi)^{-1} \tilde{x}_{t+1},
\end{gathered}
$$

and

$$
\tilde{e}_{r}=\mathfrak{l}_{2}^{\prime}(I-\rho \Pi)^{-1} \tilde{x}_{t+1} .
$$

Because the world market excess return is listed first, we can also write

$$
\tilde{e}_{e m}=\rho a_{1}^{\prime}(I-\rho \Pi)^{-1} \tilde{x}_{t+1}
$$

and

$$
\tilde{e}_{d m}=\left[\mathfrak{l}_{1}^{\prime}+\left(\mathfrak{l}_{2}^{\prime}+\rho a_{1}^{\prime}\right)(I-\rho \Pi)^{-1}\right] \tilde{x}_{t+1}
$$

where $t_{1}$ is defined analogously to $l_{2}$. Innovations in expected future excess returns and cash flows are determined by innovations $\tilde{\mathrm{x}}$ to the economic state variables, by the matrix $\Pi$ governing the evolution of the state variables, by the vectors $a_{i}$ that map state variables to expected returns, and by unexpected asset returns $\tilde{\mathrm{e}}_{1, t+1}$. The term $(\mathrm{I}-\rho \Pi)^{-1} \tilde{\mathrm{x}}_{t+1}$ that appears in the above expressions represents the revision at time $\mathrm{t}+1$ in the discounted multi-period forecast of the state vector into the infinite future. Appropriate elements are taken from this state vector forecast revision to form the components of asset returns. 
Once we have the asset return components above, it is straightforward to take ratios of covariances to variances to construct betas. In our empirical work we look at betas with the innovations in the economic state variables $\tilde{\mathrm{x}}_{t+1}$. That is, we use state variable innovations as factors, as in Chen, Roll, and Ross (1986) or Ferson (1990). The innovation in the market return is just the first element of $\tilde{\mathbf{x}}_{t+1}$. In addition to the beta measures defined in (6) and (7), we will also examine a beta that measures the sensitivity of dividend growth news in a particular country to global cash flow news:

$$
\beta_{d i, d m} \equiv \frac{\operatorname{Cov}\left(\tilde{e}_{d i}, \tilde{e}_{d m}\right)}{\operatorname{Var}\left(\tilde{e}_{d m}\right)}
$$

Ammer and Mei (1993) associate correlations among countries' dividend growth news with real economic integration.

\section{Beta Decomposition for National Stock Markets}

For the period from January 1972 to December 1990, we decompose the risk factor loadings of the U.S. dollar excess (over the one-month treasury bill rate) returns on the Morgan Stanley Capital International (MSCI) world stock market index and the dollar excess returns on fifteen national stock markets (also from MSCI) -- those of the United States, Japan, Canada, and the twelve European countries with the largest market capitalization at the end of our sample period. ${ }^{5}$ To implement our decomposition, we first estimate a VAR(1) in

${ }^{5}$ These countries are the United Kingdom, Germany, France, Switzerland, Italy, Netherlands, Spain, Sweden, Belgium, Denmark, Austria, and Norway. 
five state variables: the world stock index excess return, the (ex post) real U.S. treasury bill return, the MSCI world index dividend-price ratio, and weighted average measures of world inflation and world industrial production growth. ${ }^{6}$ The weights for the latter two variables are the 1990 GDP shares of our fifteen countries, compared at purchasing power parity (PPP) exchange rates estimated by the Organization for Economic Cooperation and Development (OECD). ${ }^{7}$ The vectors $\mathrm{a}_{\mathrm{i}}$ are then estimated by regressing the sixteen excess returns on the five state variables, the excess return components are computed from equations (11)-(15), and the beta components are calculated from (6), (7), and (16).

Table 1 presents the estimated sensitivity of news about cash flow to innovations in world market returns, the real interest rate, the world dividend yield, the global inflation rate, and the global growth rate of industrial production. The table shows that an unexpected increase in the ex post real U.S. interest rate is strongly associated with an increase in expected future cash flows on nearly all of the national portfolios. This finding is broadly consistent with a procyclical real interest rate in the context of internationally integrated financial markets. Positive innovations in dividend yields also tend to increase expected future cash flows in most of the countries, suggesting that shocks to the dividend growth rate are persistent. Increases in the world inflation rate, on the other hand, are associated with downward revisions in expected (real) future cash flows. These inflation and real interest rate results contradict the notion that stocks are a good hedge against inflation. The inflation result is not surprising given the negative relation between future cash flow innovations and

\footnotetext{
${ }^{6}$ The $\mathrm{D} / \mathrm{P}$ ratio is computed from dividends paid over the previous 12 months.

${ }^{7}$ See OECD (1992).
} 
current news about inflation found by Ammer (1994) for many of the same countries.

Industrial production shocks, however, generally have negligible implications for future dividends, perhaps because monthly industrial production data tends to be a very noisy signal of economic activity. ${ }^{8}$

Table 2 presents the estimated sensitivity of news about future expected real returns to innovations in economic state variables. We can see that unexpected increases in the world dividend yield are generally positively related to news about future expected returns, which, at least for the United States and the United Kingdom, is not surprising given the well-documented stylized fact for those countries that high dividend yields have presaged high returns. ${ }^{9}$ Inflation innovations, on the other hand, tend to lower expected future returns on many country portfolios. This contradicts the conventional wisdom that periods of high inflation are risky periods during which investors require stock returns that are high on average, and it is also consistent with the relation between expected future stock returns and own-country inflation innovations found by Ammer (1994) for a subset of these countries.

Table 3 reports factor betas for the future real interest rate news component that is common to all sixteen asset returns. The positive real interest rate beta reflects persistence in real interest rate shocks. Most of the other betas in this table are close to zero, because our state variable have little forecasting power for future real interest rates.

\footnotetext{
${ }^{8}$ Chen, Roll, and Ross (1986), among others, have found a striking lack of correlation between high frequency U.S. industrial production data and stock prices. Using lower frequency data, Fama (1990) found that equity returns led output.

${ }^{9}$ In addition, Campbell and Hamao (1992) note that the U.S. D/P ratio predicts Japanese stock returns.
} 
Much of the variability in stock returns is associated with changing expected future returns. Since the overall return sensitivity to the innovation in a state variable, $\beta_{i, k}$, is just the cash flow sensitivity less the expected future return sensitivity, and less the interest rate sensitivity, we can combine Tables 1,2 , and 3 to get the implied values for $\beta_{i, k}$. These numbers are reported in Table 4. For example, an unexpected $1 \%$ increase in the monthly ex post real interest rate is associated with a $0.96 \%(4.59 \%-1.19 \%-2.44 \%)$ excess return on the world market. For both the aggregate market and for several national stock market portfolios, the positive impact of the real interest rate on cash flows outweighs the negative impact of an increase in expected future returns and future real rates. In other words, the world's stock markets would be even more sensitive to inflation if expected returns were constant. ${ }^{10}$

A proxy for the degree of integration of a country into the real world economy can be derived from the beta of a country's cash flow news with the world's cash flow news (as opposed to the beta with the overall market return, which is also driven by news about future market returns). ${ }^{11}$ Table 5 presents estimates of this alternative beta. We use the notation $\beta_{\mathrm{di}, \mathrm{dm}}$ to indicate that this is the sensitivity of news about future cash flows on asset $\mathrm{i}, \mathrm{e}_{\mathrm{di}}$, towards news about future cash flows of the market, $e_{\mathrm{dm}}$. These cash flow-cash flow betas

${ }^{10}$ Overall, the story is consistent with Feldstein (1980), who noted that corporate tax distortions can allow inflation to drive a "wedge" between the return to investors and the cost of capital. This could simultaneously reduce investors expected returns, profit growth, and the level of the investment. The relative magnitude of the first two effects determines the correlation between contemporaneous stock return and inflation innovations. See Ammer (1994) for details.

${ }^{11}$ See Ammer and Mei (1993) for an argument in support of this sort of measure. 
vary substantially cross-sectionally, ranging from below zero to above two, and they appear to be negatively correlated with the size of the economy. Perhaps a smaller country has less scope for business cycle fluctuations that are asynchronous with those of its neighbors.

\section{Conclusions}

In this paper, we have used a dynamic accounting framework to associate unexpected asset returns with changing expectations of future cash flows, on the one hand, and discount rates, on the other hand. We have then calculated the betas of the individual components with the aggregate world market and with various economic state variables. This approach has produced several intriguing results.

First, both expected return betas and cash flow betas typically account for a significant part of overall betas. This result contrasts with that of Campbell and Mei (1993), who found, using only U.S. data, that the expected return component tended to account for most of the factor betas of size and industry portfolios. The lower degree of covariation in discount rates in our sample is consistent with the view that our fifteen national stock markets were not perfectly integrated over the 1970s and 1980s. Second, variation in expected returns on national stock markets generally has the effect of increasing their betas with the world market. Third, cash flow betas and expected return betas often have opposing effects on the overall betas of assets with economic state variables. For example, when inflation increases, a negative effect on cash flows typically outweighs a positive effect on the current return that derives from a downward revision in future expected returns. Fourth, we find some assets have positive betas with respect to some of the state variables, while others have negative 
betas with respect to these variables. This is quite interesting because it tells us how certain world economic risk can be reduced by having a diversified international portfolio. The stock markets of several of the smaller countries, such as Austria and Denmark, appear to have substantial hedge potential. The cash flow and expected return betas are also helpful for certain strategies for risk hedging. 


\section{References}

Ammer, John, 1994, "Inflation, Inflation Risk, and Stock Returns," International Finance Discussion Paper 464, Federal Reserve Board (April).

Ammer, John and Jianping Mei, 1993, "Measuring International Economic Linkages with Stock Market Data," International Finance Discussion Paper 449, Federal Reserve Board (August).

Bekaert, Geert and Robert J. Hodrick, 1992, "Characterizing Predictable Components in Excess Returns on Equity and Foreign Exchange Markets," Journal of Finance 47:467-510.

Campbell, John Y., 1991, "A Variance Decomposition for Stock Returns," the H.G. Johnson Lecture to the Royal Economic Society, Economic Journal 101:157-179.

Campbell, John Y. and John Ammer, 1993, "What Moves the Stock and Bond Markets? A Variance Decomposition for Long-Term Asset Returns," Journal of Finance 48:3-37.

Campbell, John Y. and Yasushi Hamao, 1992, "Predictable Returns in the United States and Japan: A Study of Long Term Capital Markets Integration," Journal of Finance 47:43-70.

Campbell, John Y. and Jianping Mei, 1993, "Where Do Betas Come From? Asset Price Dynamics and the Sources of Systematic Risk," Review of Financial Studies 6:567-592.

Campbell, John Y. and Robert J. Shiller, 1988, "The Dividend-Price Ratio and Expectations of Future Dividends and Discount Factors," Review of Financial Studies 1:195-228.

Chen, Nai-fu, 1991, "Financial Investment Opportunities and the Macroeconomy," Journal of Finance 46:529-554.

Chen, Nai-fu, Richard Roll, and Stephen A. Ross, 1986, "Economic Forces and the Stock Market," Journal of Business 59:383-403.

Connor, Gregory and Robert A. Korajczyk, 1989, "An Intertemporal Beta Pricing Model," Review of Financial Studies 2:373-392.

Elton, Edwin J., Martin J. Gruber and Thomas Urich, 1978, "Are Betas Best?," Journal of Finance 13:1375-1384.

Fama, Eugene F., 1990, "Stock Returns, Expected Returns, and Real Activity," Journal of Finance 45:1089-1108.

Fama, Eugene F. and Kenneth R. French, 1988a, "Permanent and Temporary Components of Stock Prices," Journal of Political Economy 96:246-273. 
Fama, Eugene F. and Kenneth R. French, 1988b, "Dividend Yields and Expected Stock Returns," Journal of Financial Economics 22:3-25.

Fama, Eugene F. and Kenneth R. French, 1989, "Business Conditions and Expected Returns on Stocks and Bonds," Journal of Financial Economics 25:23-49.

Feldstein, Martin, 1980, "Inflation and the Stock Market," American Economic Review 70:839-847.

Ferson, Wayne E. and Campbell R. Harvey, 1991, "The Variation of Economic Risk Premiums," Journal of Political Economy 99:385-415.

Gultekin, Mustafa N. and N. Bulent Gultekin, 1983, "Stock Market Seasonality: International Evidence," Journal of Political Economy 12:469-481.

Gultekin, Mustafa N., N. Bulent Gultekin and Alessandro Penati, 1989, "Capital Controls And International Capital Market Segmentation: The Evidence From the Japanese and American Stock Markets," Journal of Finance 44:849-870.

Hodrick, Robert J., 1991, "Dividend Yields and Expected Stock Returns: Alternative Procedures for Inference and Measurement," Working Paper No. 88, Department of Finance, Kellogg School, Northwestern University.

Ibbotson Associates, 1991, Stocks, Bonds, Bills, and Inflation.

Kandel, Shmuel and Robert F. Stambaugh, 1988, "Modelling Expected Stock Returns for Short and Long Horizons," Working Paper 42-88, Rodney L. White Center for Financial Research, Wharton School, University of Pennsylvania.

Keim, Donald B. and Robert F. Stambaugh, 1986, "Predicting Returns in the Stock and Bond Markets," Journal of Financial Economics 17:357-390.

Lo, Andrew and A. Craig MacKinlay, 1988, "Stock Market Prices Do Not Follow Random Walks: Evidence from a Simple Specification Test," Review of Financial Studies 1:41-66.

OECD, 1992, "1990 Purchasing Power Parities and Real Expenditures," Paris.

Roll, Richard, 1992, "Industrial Structure and the Comparative Behavior of International Stock Market Indexes, Journal of Finance 47:1-42.

Sims, Christopher A., 1980, "Vector Autoregressions and Reality," Econometrica 48:1-48.

Stambaugh, Robert F., 1990, "Factors in Expected Returns," unpublished paper, Wharton School, University of Pennsylvania. 
Stockman, Alan C. and Lars E.O. Svensson, "Capital Flows, Investment, and Exchange Rates," Journal of Monetary Economics 17:357-390. 
Table 1

Observable Factor Betas of National Stock Market Cash Flow News $\left(\beta_{\text {di, }}\right)$

January 1972 - December 1990

\begin{tabular}{||c||c|c|c|c|c||}
\hline \multicolumn{1}{|c|}{$\begin{array}{c}\text { national } \\
\text { stock market }\end{array}$} & $\begin{array}{c}\text { world } \\
\text { stock } \\
\text { market }\end{array}$ & $\begin{array}{c}\text { real U.S. } \\
\text { interest } \\
\text { rate }\end{array}$ & $\begin{array}{c}\text { world } \\
\text { dividend } \\
\text { yield }\end{array}$ & $\begin{array}{c}\text { world } \\
\text { inflation } \\
\text { rate }\end{array}$ & $\begin{array}{c}\text { world } \\
\text { industrial } \\
\text { production }\end{array}$ \\
\hline \hline world portfolio & 0.64 & 4.59 & 5.85 & -0.28 & -0.02 \\
\hline Austria & 1.66 & 15.28 & -9.88 & -0.80 & -0.04 \\
\hline Belgium & 0.60 & 8.49 & 2.18 & -0.47 & -0.03 \\
\hline Canada & 0.23 & -1.90 & 10.68 & -0.04 & 0.00 \\
\hline Denmark & 0.30 & 6.98 & -1.40 & -0.32 & 0.01 \\
\hline France & 0.09 & 1.64 & 12.11 & -0.08 & 0.00 \\
\hline Germany & -0.13 & 1.35 & 11.13 & -0.05 & -0.01 \\
\hline Italy & 0.03 & 4.10 & 8.66 & -0.12 & 0.03 \\
\hline Japan & 0.71 & 6.95 & 3.45 & -0.36 & 0.01 \\
\hline Netherlands & -0.27 & 0.17 & 14.06 & 0.02 & -10.00 \\
\hline Norway & 1.65 & 9.62 & -1.40 & -0.55 & -10.02 \\
\hline Spain & 1.41 & 14.47 & -7.08 & -0.66 & -0.05 \\
\hline Sweden & -0.36 & 2.62 & 18.19 & 0.10 & 0.01 \\
\hline Switzerland & 0.21 & 3.79 & 7.99 & -0.22 & -10.02 \\
\hline United Kingdom & -0.42 & -2.21 & 19.55 & 0.18 & -10.03 \\
\hline United States & 0.32 & 2.84 & 8.17 & -0.14 & -0.01 \\
\hline
\end{tabular}

Notes: All stock returns are measured in dollars as the excess over the treasury bill rate. The dividend yield is based on dividends paid on the world index over the previous 12 months. Inflation and industrial production growth are averages for the 15 countries using GDP (at purchasing power parity) weights from OECD (1992). All data units are percent per month. 
Table 2

Observable Factor Betas of National Stock Market Future Return News $\left(\beta_{\text {ei,k }}\right)$

January 1972 - December 1990

\begin{tabular}{|c|c|c|c|c|c|}
\hline $\begin{array}{c}\text { national } \\
\text { stock nnarket }\end{array}$ & $\begin{array}{c}\text { world } \\
\text { stock } \\
\text { market }\end{array}$ & $\begin{array}{c}\text { real U.S. } \\
\text { interest } \\
\text { rate }\end{array}$ & $\begin{array}{l}\text { risk factor } \\
\text { world } \\
\text { dividend } \\
\text { yield }\end{array}$ & $\begin{array}{l}\text { world } \\
\text { inflation } \\
\text { rate }\end{array}$ & $\begin{array}{c}\text { world } \\
\text { industrial } \\
\text { production }\end{array}$ \\
\hline world portfolio & -0.38 & 1.19 & 4.66 & -0.12 & 0.00 \\
\hline Austria & 1.38 & 11.85 & -11.86 & -0.68 & -0.04 \\
\hline Belgium & -0.04 & 4.87 & 1.00 & -0.34 & -0.01 \\
\hline Canada & -0.69 & -3.76 & 9.27 & 0.13 & 0.02 \\
\hline Denmark & -0.14 & 4.22 & 0.17 & -0.20 & 0.02 \\
\hline France & -0.78 & -1.90 & 9.52 & 0.04 & 0.03 \\
\hline Germany & -0.74 & -2.33 & 9.89 & 0.10 & 0.01 \\
\hline Italy & -0.64 & 0.20 & 8.30 & 0.04 & 0.01 \\
\hline Japan & -0.07 & 3.65 & 3.02 & -0.23 & 0.02 \\
\hline Netherlands & -0.99 & -3.13 & 12.13 & 0.15 & 0.03 \\
\hline Norway & 0.81 & 8.83 & -7.56 & -0.59 & -0.02 \\
\hline Spain & 0.81 & 10.39 & -6.95 & -0.52 & -0.03 \\
\hline Sweden & -0.98 & -2.55 & 12.48 & 0.20 & 0.01 \\
\hline Switzerland & -0.54 & -0.16 & 6.56 & -0.06 & 0.00 \\
\hline United Kingdom & -1.46 & -6.68 & 16.31 & 0.33 & -0.02 \\
\hline United States & -0.61 & -0.85 & 6.50 & 0.03 & 0.01 \\
\hline
\end{tabular}

Notes: All stock returns are measured in dollars as the excess over the treasury bill rate. The dividend yield is based on dividends paid on the world index over the previous 12 months. Inflation and industrial production growth are averages for the 15 countries using GDP (at purchasing power parity) weights from OECD (1992). All data units are percent per month. 
Table 3

Observable Factor Betas of U.S. Real Interest Rate News $\left(\beta_{r, k}\right)$

January 1972 - December 1990

\begin{tabular}{||c||c|c|c|c|c||}
\hline \multicolumn{1}{|c||}{} & \multicolumn{5}{|c|}{ risk factor } \\
& $\begin{array}{c}\text { world } \\
\text { stock } \\
\text { market }\end{array}$ & $\begin{array}{c}\text { real U.S. } \\
\text { interest } \\
\text { rate }\end{array}$ & $\begin{array}{c}\text { world } \\
\text { dividend } \\
\text { yield }\end{array}$ & $\begin{array}{c}\text { world } \\
\text { inflation } \\
\text { rate }\end{array}$ & $\begin{array}{c}\text { world } \\
\text { industrial } \\
\text { production }\end{array}$ \\
\cline { 2 - 6 }$\beta_{\mathrm{r}, \mathrm{k}}$ & 0.02 & 2.44 & -0.60 & -0.09 & -0.00 \\
\hline
\end{tabular}


Table 4

Observable Factor Betas of National Stock Market Returns $\left(\boldsymbol{\beta}_{i, \mathrm{k}}\right)$

January 1972 - December 1990

\begin{tabular}{||c||c|c|c|c|c||}
\hline \multicolumn{1}{|c||}{$\begin{array}{c}\text { national } \\
\text { stock market }\end{array}$} & $\begin{array}{c}\text { world } \\
\text { stock } \\
\text { market }\end{array}$ & $\begin{array}{c}\text { real U.S. } \\
\text { interest } \\
\text { rate }\end{array}$ & $\begin{array}{c}\text { world } \\
\text { dividend } \\
\text { yield }\end{array}$ & $\begin{array}{c}\text { world } \\
\text { inflation } \\
\text { rate }\end{array}$ & $\begin{array}{c}\text { world } \\
\text { industrial } \\
\text { production }\end{array}$ \\
\hline world portfolio & 1.00 & 0.96 & 1.79 & -0.06 & -0.02 \\
\hline Austria & 0.25 & 0.99 & 2.58 & -0.03 & 0.00 \\
\hline Belgium & 0.62 & 1.19 & 1.78 & -0.04 & -0.01 \\
\hline Canada & 0.90 & -0.58 & 2.01 & -0.09 & -0.01 \\
\hline Denmark & 0.41 & 0.32 & -0.96 & -0.02 & -0.01 \\
\hline France & 0.85 & 1.10 & 3.19 & -0.03 & -0.02 \\
\hline Germany & 0.58 & 1.24 & 1.84 & -0.05 & -0.03 \\
\hline Italy & 0.65 & 1.46 & 0.97 & -0.07 & 0.02 \\
\hline Japan & 0.77 & 0.86 & 1.04 & -0.04 & -0.01 \\
\hline Netherlands & 0.70 & 0.85 & 2.54 & -0.04 & -0.03 \\
\hline Norway & 0.82 & -1.65 & 6.76 & 0.14 & 0.01 \\
\hline Spain & 0.58 & 1.65 & 0.47 & -0.04 & -0.01 \\
\hline Sweden & 0.60 & 2.73 & 6.31 & -0.01 & 0.01 \\
\hline Switzerland & 0.72 & 1.51 & 2.03 & -0.07 & -0.02 \\
\hline United Kingdom & 1.01 & 2.04 & 3.84 & -0.06 & -0.01 \\
\hline United Sitates & 0.91 & 1.25 & 2.27 & -0.08 & -0.02 \\
\hline
\end{tabular}

Notes: All stock returns are measured in dollars as the excess over the treasury bill rate. The dividend yield is based on dividends paid on the world index over the previous 12 months. Inflation and industrial production growth are averages for the 15 countries using GDP (at purchasing power parity) weights from OECD (1992). All data units are percent per month. 
Table 5

World Stock Market Cash Flow News Betas of National Stock Market Cash Flow News January 1972 - December 1990

\begin{tabular}{||l|c||}
\hline \multicolumn{1}{|c|}{$\begin{array}{c}\text { national } \\
\text { stock market }\end{array}$} & $\boldsymbol{\beta}_{\text {didm }}$ \\
\hline \hline world portfolio & 1.00 \\
\hline Austria & 2.48 \\
\hline Belgium & 1.15 \\
\hline Canada & 0.34 \\
\hline Denmark & 0.65 \\
\hline France & 0.28 \\
\hline Germany & 0.02 \\
\hline Italy & 0.24 \\
\hline Japan & 1.14 \\
\hline Netherlands & -0.18 \\
\hline Norway & 2.25 \\
\hline Spain & 2.12 \\
\hline Sweden & -0.28 \\
\hline Switzerland & 0.52 \\
\hline United Kingdom & -0.45 \\
\hline United States & 0.55 \\
\hline
\end{tabular}




\section{International Finance Discussion Papers}

IFDP

Number

Titles

Author(s)

$\underline{1995}$

$502 \quad$ Strategic Returns to International

Diversification: An Application to the Equity

John Ammer

Markets of Europe, Japan, and North America

Jianping Mei

501 Real Exchange Rate Movements in High Inflation

Countries

John H. Rogers

Ping Wang

Diane Lim Rogers

Political Competition, Casual Relations Between

Taxes and Spending, and Their Influence on

Government Size: Evidence From State-Level Data

John H. Rogers

499 International Stock Price Spillovers and

Market Liberalization: Evidence From

Korea, Japan, and the United States

Sang W. Kim

John H. Rogers

$498 \quad$ How Wide is the Border?

Charles Engle

John H. Rogers

David Bowman

with Limited Communication

496 Saving-Investment Associations and Capital

Mobility On the Evidence from Japanese

Regional Data

495 Convertibility Risk, Default Risk, and the Mexdollar Anomaly

494 Government Budget Deficits and Trade Deficits:

Are Present-Value Constraints Satisfied in

Long-Term Data?

493 Real Shocks and Real Exchange Rates in Really

Long-Term Data

$\underline{1994}$

492

Loss Aversion in a Consumption/Savings Model

David Bowman

Deborah Minehart

Matthew Rabin

491 Terms-of-Trade Uncertainty and Economic Growth Are Risk Indicators Significant in Growth

Enrique G. Mendoza Regressions

Please address requests for copies to International Finance Discussion Papers, Division of International Finance, Stop 24, Board of Governors of the Federal Reserve System, Washington, D.C. 20551. 


\section{International Finance Discussion Papers}

IFDP

Number

490 $\underline{\text { Titles }}$

Author's)

1994

Politics, Economics, and Investment: Explaining Plant and Equipment Spending by U.S. Direct Investors in Argentina, Brazil, and Mexico

On The Dynamic Properties of Asymmetric Models of Real GNP

A distributed block approach to solving near-block-diagonal systems with an application to a large macroeconometric model

Conditional and Structural Error Correction Models

Bank Positions and Forecasts of Exchange Rate Movements

Technological Progress and Endogenous Capital Depreciation: Evidence from the U.S. and Japan

Are Banks Market Timers or Market Makers? Explaining Foreign Exchange Trading Profits

Constant Returns and Small Markups in U.S.

Manufacturing

The Real Exchange Rate and Fiscal Policy During the Gold Standard Period: Evidence from the United States and Great Britain

The Debt Crisis: Lessons of the 1980s for the 1990s

Who Will Join EMU? Impact of the Maastricht Convergence Criteria on Economic Policy Choice and Performance

Determinants of the 1991-93 Japanese Recession: Evidence from a Structural Model of the Japanese Economy

On Risk, Rational Expectations, and Efficient Asset Markets

Finance and Growth: A Synthesis and Interpretation of the Evidence

Trade Barriers and Trade Flows Across Countries and Industries
Guy V.G. Stevens

Allan D. Brunner

Jon Faust

Ralph Tryon

Neil R. Ericsson

Michael P. Leahy

Robert Dekle

John Ammer

Allan D. Brunner

Susanto Basu

John G. Fernald

Graciela L. Kaminsky

Michael Klein

Graciela L. Kaminsky

Alfredo Pereira

R. Sean Craig

Allan D. Brunner Steven B. Kamin

Guy V.G. Stevens

Dara Akbarian

Alexander Galetovic

Jong-Wha Lee Phillip Swagel 